\title{
Electrocardiographic patterns of Mangalarga Marchador horses before and after implementation of the marcha gait
}

\author{
Padrões eletrocardiográficos em equinos da raça Mangalarga \\ Marchador antes e após a execução da marcha \\ Clarisse Simões Coelho ${ }^{\mathrm{I}^{*}}$ Gabriella Agra de Omena e SilvaII \\ Luiz Antonio Trindade Oliveira Junior ${ }^{I}$ Vanessa Sartor Moraes ${ }^{I}$ \\ Laura Monteiro de Castro Conti ${ }^{\mathrm{I}}$ Tatiana Champion ${ }^{\mathrm{III}}$
}

ABSTRACT

The aim of this study was to evaluate the electrocardiographic parameters in Mangalarga Marchador horses submitted to marcha exercise. Twenty-four Mangalarga Marchador horses, thirteen females and eleven males, $6.4 \pm 2.7$ years old with a mean weight of $428.3 \pm 24.7 \mathrm{~kg}$, were used. Electrocardiograms were recorded in two different moments: rest and immediately after exercise (40 minutes of aerobic exercise, marchagait). The electrocardiographic variables analyzed were cardiac rhythm, heart rate (HR), duration of $P$ wave, QRS complex, $P R$ and $Q T$ intervals, amplitudes of $P, R$ and $T$ waves, and analysis of $Q T$ corrected (QTc) according to Bazett's formula $(Q T / \sqrt{ } R R)$. Variables were analyzed for normality with Kolmogorov-Smirnov test and paired t-test, considering $P<0.05$. Rhythm analysis revealed $91.7 \%$ of sinus rhythm and $8.3 \%$ of sinus arrhythmia in rest, with mean HR of $45.7 \pm 12.7$ beats minute ${ }^{-1}$, and $100 \%$ of sinus tachycardia, with mean HR of $77.3 \pm 13.5$ beats minute ${ }^{-1}$ after exercise $(P<0.0001)$. In post-exercise, it was possible to observe decreases in $P$ wave duration $(P=0.0121), P R$ interval $(P=0.0007)$ and $Q T$ interval $(P<0.0001)$ and increase of $Q T c(P=0.0039)$ and $R$ wave amplitude $(P=0.0033)$. There were no significant differences for amplitude of $P$ and $T$ waves and QRS complex related to atrioventricular enlargement. Although $Q T$ interval decreased after exercise, there was an increase on QTc after exercise, indicating changes in ventricular repolarization. It was possible to conclude that the imposed exercise (marcha gait) led to electrocardiographic alterations without causing pathological arrhythmias.

Key words: horses, electrocardiogram, exercise.

RESUMO

O objetivo deste estudo foi avaliar os parâmetros eletrocardiográficos de equinos da raça Mangalarga Marchador antes e após a execução da marcha. Para tal, foram usados 24 equinos, treze fêmeas e onze machos, com idade média de $6,4 \pm 2,7$ anos e peso médio de 428,3 $\pm 24,7 \mathrm{~kg}$. Eletrocardiogramas foram registrados em dois momentos: antes e imediatamente após atividade física (40 minutos de marcha). As variáveis eletrocardiográficas analisadas foram ritmo cardíaco, frequência cardíaca (FC), duração da onda $P$, complexo $Q R S$, intervalos $P R$ e QT, amplitudes das ondas $P, R$ e $T$ e análise do $Q T$ corrigida (QTc) de acordo com a fórmula de Bazett $(Q T / \sqrt{ } R R)$. As variáveis foram analisadas quanto à normalidade (teste de KolmogorovSmirnov), seguido da comparação usando teste-t pareado $(P<0,05) . A$ análise revelou $91,7 \%$ de ritmo sinusal e $8,3 \%$ de arritmia sinusal no repouso, com FC média de 45,7士12,7bpm e $100 \%$ de taquicardia sinusal após o exercício, com FC média de $77,3 \pm 13,5 \mathrm{bpm}(P<0,0001)$. No pós-exercício, foi possivel observar reduções significativas na duração da onda $P(P=0,0121)$, no intervalo $P R(P=0,0007)$ e no intervalo $Q T(P<0,0001)$, além de aumentos significativos de QTc $(P=0,0039)$ e amplitude da onda $R(P=0,0033)$. Não foram registradas diferenças para a amplitude das ondas $P$ e Te na duração do complexo QRS. Apesar da redução no intervalo $Q T$ após o exercício, houve um aumento no QTc, indicando alterações na repolarização ventricular. Foi possível concluir que a atividade fisica (marcha) gerou alterações eletrocardiográficas, sem causar arritmias patológicas.

Palavras-chave: cavalos, eletrocardiograma, exercício.

\section{INTRODUCTION}

Research in the area of exercise physiology is necessary in order to understand how training and competitions influence physiological and biochemical

'Faculdade de Medicina Veterinária e Programa de Pós-graduação em Ciência Animal, Universidade Vila Velha (UVV), Rua Comissário José Dantas de Melo, 21, 29101-130, Vila Velha, ES, Brasil. E-mail: clarisse.coelho@uvv.br. "Corresponding author.

"Faculdade de Medicina Veterinária, Universidade Vila Velha (UVV), Vila Velha, ES, Brasil.

IIIFaculdade de Medicina Veterinária, Universidade Federal da Fronteira Sul (UFFS), Chapecó, SC, Brasil. 
variables (MARQUES et al., 2002). Thereby, it is possible to use this information when evaluating equine athletic conditioning during physical exercise and also in the evaluation of training programs (GAMA et al., 2012). Among various horse breeds, Mangalarga Marchador can be highlighted, with a distinctive way of moving, called marcha gait, in which the animal performs a long-term exercise without rest and at constant speed, with great energy expenditure. During the gait, horse alternates between diagonal and lateral supports, always understated by an intermediate period called triple hoof support; moment in which three limbs of horse touch 'the ground at the same time (REZENDE, 2006).

With exercise, circulatory demand increases and, heart provides greater circulating volume per minute through increased heart rate and increased contraction force (MENDES, 2004). According to ALBERNAZ et al. (2011), the major complication of heart adaptation in horses is heart size compared to animal weight and, particularly, susceptibility to cardiac arrhythmias mediated by the vagal tonus is present in this species, and tends to disappear with exercise (VINCENZI et al., 2000; MARR \& BOWEN, 2010).

Electrocardiogram (ECG) has been used in athletic performance assessment, when monitoring physical training and its excesses and also for heart disease identification, associated with a careful physical examination (DINIZ et al., 2008; MARR \& BOWEN, 2010). It is an inexpensive test, non-invasive and easy to perform, which provides information about both frequency and cardiac rhythm (ALBERNAZ et al., 2011).

FERNANDES et al. (2004) reported that electrocardiographic parameters have specific patterns according to each species and breed. Such differences occur depending on morphology and physical fitness of horses. Some studies have been conducted on animals at rest to establish breed differences, including Thoroughbred (FERNANDES et al., 2004), Mangalarga Marchador (DINIZ et al., 2008), and Crioulo (LISBOA et al., 2009), but only the latter used athletic animals.

According to YOUNG et al. (2007), ECG of horses at rest has limited value because cardiac diseases and disturbances in cardiac rhythm, leading to decreased performance, rarely manifest themselves during rest. Additionally, some arrhythmias tend to appear during recovery period after physical activity, due to rapid changes in autonomic control (MARR \& BOWEN, 2010). MORRIS \& SEEHERMAN (1991) emphasize that most heart disease in athletic horses manifest in medium to high speeds. To characterize whether arrhythmia found during physical examination is or not clinically important, it is therefore necessary to carry out physical stress tests (MARR \& BOWEN, 2010), in which good quality of records is essential as well as the evaluator experience (TRACHSEL et al., 2010). Proving this assertion, MARTIN et al. (2000) diagnosed 33 cases of significant cardiac arrhythmias leading to poor performance through ECG performed before and in different moments after physical activity; and BUHL et al. (2010) reported a significant interaction between arrhythmias and time of ECG (rest, exercise, and recovery), with a large number of changes occurring during immediate post-exercise recovery. This was also described by BARBESGAARD et al. (2010). FAZIO et al. (2003) and YONEZAWA et al. (2009) noted that ECG before and at different intervals after exercise was important in evaluation of cardiac changes promoted by physical activity.

The present study aimed to evaluate electrocardiographic patterns in Mangalarga Marchador horses before and after performing physical activity of moderate intensity characterized by 40 minutes of marcha gait.

\section{MATERIALS AND METHODS}

Twenty-four Mangalarga Marchador horses were used, 13 females and 11 males, with an average weight of $428.3 \pm 24.7 \mathrm{~kg}$ and aged between 3 and 11 years (average 6.4 \pm 2.7 years), all considered healthy in previous physical examinations. Animals were raised in two properties located in the city of Guarapari, Espírito Santo, Brazil (LAT-20.654198, LONG-40.498702).

All horses underwent same food and health management. Feed was made with coast-cross hay (Cynodon dactylon) and, inorganic mineral salt (Essencefós, Nutrimentos Presence, Paulínia, SP, Brazil) ad libitum and commercial feed $\left(1.2 \mathrm{~kg} 100 \mathrm{~kg}^{-}\right.$ 1 body weight - Corcel Tradicional, Nutrimentos Presence, Paulínia, SP, Brazil) with $12 \%$ crude protein, divided into three times daily. Water was always available.

Selected horses were in same athletic conditioning and have been training for at least six months. Training consisted of a 60 -minutes walking without a rider, twice a week, alternating with a 30 40 minutes of marcha with rider on other three days. On weekends animals were submitted to a 20 minutes period of marcha gait with rider on each day.

Animals were evaluated at two moments: T0 (before physical activity) and T1 (a maximum 
period of 5 minutes after the end of physical activity). For present research, horses executed marcha for 40 minutes, 20 minutes clockwise and another 20 minutes counter clockwise, in a similar protocol established by the Associação Brasileira de Criadores de Cavalos da raça Mangalarga Marchador (ACCMM - Brazilian Association of Mangalarga Marchador Horses Owners). Physical activities were performed during morning period (between 6 am and $11 \mathrm{am}$ ), when also racetrack characteristics were recorded. Two riders with mean weight of $70 \mathrm{~kg}$ and mean height of $1.73 \mathrm{~m}$ were used. Auscultation was performed and animals were free of cardiac murmurs.

Electrocardiograms, each lasting 3-5 minutes, were obtained from each horse in $\mathrm{T} 0$ and T1 using 12-channel ECG-PC electrocardiograph (Tecnologia Eletrônica Brasileira-TEB, São Paulo, SP, Brazil), being careful to keep animals with their limbs parallel to each other and perpendicular to body axis. Alligator clips fixed to electrocardiographic electrodes were attached directly to skin. Electrodes were placed on caudal aspect of forelimbs on the level of olecranon and on hind limbs, lateral to stifle joint to record bipolar leads I, II and III and unipolar leads aVR, aVF and aVL. All recordings were taken with horse standing near track. Tracings were obtained, recorded and standardized with $\mathrm{N}$ sensitivity and $25 \mathrm{~mm} \mathrm{~s}^{-1}$ speed; for interpretation of electrocardiographic tracings, bipolar lead DII was used. Study of tracings involved measurement of $\mathrm{P}$, $\mathrm{R}$, and $\mathrm{T}$ wave amplitudes (in $\mathrm{mV}$ ) and duration (in $\mathrm{ms}$ ) of P wave, QRS complex, PR and QT intervals, as well as determining heart rate and rhythm. Corrected QT (QTc) was calculated according to Bazett's formula $(\mathrm{QT} / \sqrt{\mathrm{RR}})$. Evaluation of these characteristics was based on FERNANDES et al. (2004), using frontal plane.

Additionally, during exercise, horses used a heart monitor with GPS (RS800CX-G3, Polar Electro, Lake Success, NY, USA) in order to record speed and distance achieved by each animal. Data were analyzed using the ProTrainer 5 program. Monitoring of exercise intensity was done by determining plasma lactate and evaluation of $\mathrm{HR}$ in the moments before (T0), immediately after physical activity conclusion (T1), and after 30 minutes (T2).

Results were analyzed using the GraphPad Instat 3.0 statistical program. Data were submitted to a normality test (Kolmorov Smirnov test) being considered parametric when $\mathrm{P}>0.10$. Later, paired t-test was used to compare the average values of the variables mentioned above and to evaluate the possible influence of the marcha gait to variables, when $\mathrm{P}<0.05$.

\section{RESULTS AND DISCUSSION}

Physical examinations performed in order to select horses revealed heart rate values of $44.7 \pm 8.2$ beats minute $^{-1}$ without pathological murmurs, respiratory rate of $26.9 \pm 8.8$ breaths per minute, presence of normal bowel sounds in abdominal auscultation, rectal temperature of $37.6 \pm 0.3^{\circ} \mathrm{C}$, and mucous membranes pinkish in color. All parameters were within normal range according to ROBINSON (2008), qualifying all animals included in the study.

Animals were evaluated in eight days, three animals per day in the month of May (autumn season in Brazil), with local temperature records of $26.5 \pm 2.8^{\circ} \mathrm{C}$ and relative humidity of $67.8 \pm 9.4 \%$, typical of tropical regions. Sand track (130m) was dry in all evaluation days. Cardiac monitor registered an average speed of $11.3 \pm 0.5 \mathrm{~km} \mathrm{~h}^{-1}$ and an average total distance of $7.2 \pm 1.1 \mathrm{~km}$ during the 40-minute gait, similar to that described by REZENDE (2006). According to riders, no signs of discomfort or reduced performance were observed during exercise execution.

Gait performed in this study was characterized as an aerobic exercise of long duration and moderate intensity (FALASCHINI \& TROMBETTA, 2001), since values recorded for plasma lactate were $1.02 \pm 0.41 \mathrm{mmol} \mathrm{L}^{-1}$ at rest (T0) and $2.73 \pm 2.43 \mathrm{mmol} \mathrm{L}^{-1}$ immediately after exercise (T1), inferior to anaerobic threshold of 4.0mmol ${ }^{-1} \mathrm{~L}$ (GAMA et al., 2012). Values recorded for HR (47.8 \pm 8.3 beats minute $\left.{ }^{-1}\right)$ and plasma lactate $\left(1.89 \pm 1.24 \mathrm{mmol} \mathrm{L}^{-1}\right) 30$ minutes after physical activity conclusion (T2) suggested that horses used were adapted to imposed physical activity level, with recovery of T0 values, as described by GAMA et al. (2012) and BELLO et al. (2012).

The most common rhythm found at rest (before the gait) was sinus rhythm, in $91.7 \%$ of used horses. These values were superior to those described by DINIZ et al. (2008), who reported a prevalence of sinus rhythm in $61.7 \%$ in the 60 Mangalarga Marchador studied. Still according to DINIZ et al. (2008), sinus arrhythmia occurred in $28.2 \%$, higher than values reported $(8.3 \%)$ in pre-marcha gait (T0) of the present study. FERNANDES et al. (2004) also described prevalence of sinus rhythm in studied Thoroughbreds, emphasizing greater prevalence in foals compared to older females. Immediately after execution of 40 -minute gait, $100 \%$ of the animals showed sinus tachycardia, which, according DUMONT et al. (2010), can be considered normal when associated with pain, excitement, or exercise. 
According to MARR \& BOWEN (2010), constant physical activity alters sympathetic-vagal balance, increasing vagal activity and reducing vulnerability to pathological arrhythmias during exercise, consistently with findings of the present study where the animals showed no pathological arrhythmias at rest or in the immediate post-exercise.

Table 1 shows mean values and standard deviations for the $\mathrm{P}, \mathrm{R}$, and $\mathrm{T}$ wave amplitudes $(\mathrm{mV})$ and duration (in $\mathrm{ms}$ ) of the $\mathrm{P}$ wave, QRS complex; PR and QT intervals; QTc analysis and heart rate (beats/minute), as well as the $p$ values obtained from paired t-test. It's possible to observe significant reductions in the duration of $\mathrm{P}$ wave, $\mathrm{PR}$ interval, and QT interval, and significant increases in QTc and $\mathrm{R}$ wave amplitude. No differences were recorded for $\mathrm{P}$ and $\mathrm{T}$ wave amplitude and for the duration of the QRS complex.

Increased HR in response to physical exercise has been described in literature (CAPELLETO et al., 2009; FERRAZ et al., 2009; BELLO et al., 2012; FOLADOR et al., 2014) and was observed in Mangalarga Marchador used in present study. Exercise-induced tachycardia is dependent on intensity of physical activity and high metabolic requirements of muscles in activity (RUMENIG et al., 2007), with a vague-dependent increase recorded in first moments and sympathetic-dependent in later periods (ALONSO et al., 1998).

Values recorded at rest for both HR and electrocardiographic variables are within normal values according to MARR \& BOWEN (2010), with oscillations differing from literature findings possibly due to breed and physical aptitude of the horses used in the various studies (FAZIO et al., 2003; FERNANDES et al., 2004; DINIZ et al., 2008; LISBOA et al., 2009; ALBERNAZ et al., 2011; BELLO et al., 2012). FAZIO et al. (2003) also described significant differences in electrocardiographic variables during moments before and after exercise in 1600, 2000, and $7000 \mathrm{~m}$, similar to this study, as did BELLO et al. (2012) evaluating ECG in polo horses before and after a chukker.

With an increase in $\mathrm{HR}$, reduction in P-wave duration and PR and QT intervals were observed after gait, similar to that found in horses exercised on treadmill (SCHEFFER \& VAN OLDRUITENBORGH-OOSTERBAAN, 1996), in trotting Italian animals at speed of $12.7 \mathrm{~m} \mathrm{~s}^{-1}$ for $1600 \mathrm{~m}$ and 2000m (FAZIO et al., 2003), in high performance animals exercised on a treadmill (YONEZAWA et al., 2009) and after chukker (game periods of 7 minutes) in polo (BELLO et al., 2012). SCHEFFER \& VAN OLDRUITENBORGH-OOSTERBAAN (1996) also complemented that increasing speed until canter promoted a greater increase in HR (compatible with exercise intensity), as well as ST segment indefinition, PQ interval shortening and a possible disappearance of the $\mathrm{P}$ wave, incorporated into previous $\mathrm{T}$ wave. Similar findings were reported by MARR \& BOWEN (2010) due to depolarization acceleration from sinus node to atrioventricular node (atrioventricular conduction) associated with increased heart rate.

As mentioned above, marcha gait generated significant increase in $\mathrm{HR}$ and consequent reduction in the QT interval, similar to found by BELLO et al. (2012) and PEDERSEN et al. (2013). PEDERSEN et al. (2013) conducted the first study evaluating the QT interval from resting period to maximal exercise in horses, and reported

Table 1- Mean values and standard deviation for amplitudes (mV) of P, R and T waves and duration (ms) of P wave, QRS complex, PR and QT intervals, QTc and heart rate (beats/minute) analysis in Mangalarga Marchador horses before (T0) and after (T1) 40 minutes of marcha gait.

\begin{tabular}{llll}
\hline & \multicolumn{1}{c}{ T0 } & T1 & P \\
\hline P $(\mathrm{mV})$ & $0.2 \pm 0.0^{\mathrm{a}^{*}}$ & $0.2 \pm 0.0^{\mathrm{a}}$ & 0.0649 \\
R (mV) & $0.4 \pm 0.3^{\mathrm{a}}$ & $0.6 \pm 0.4^{\mathrm{b}}$ & 0.0033 \\
T $(\mathrm{mV})$ & $0.4 \pm 0.2^{\mathrm{a}}$ & $0.3 \pm 0.2^{\mathrm{a}}$ & 0.2640 \\
HR (beats $\left.\min ^{-1}\right)$ & $45.7 \pm 12.7^{\mathrm{a}}$ & $77.3 \pm 13.5^{\mathrm{b}}$ & $<0.0001$ \\
P (ms) & $86.3 \pm 22.1^{\mathrm{a}}$ & $77.7 \pm 14.2^{\mathrm{b}}$ & 0.0121 \\
PR (ms) & $225.7 \pm 43.8^{\mathrm{a}}$ & $196.0 \pm 32.1^{\mathrm{b}}$ & 0.0007 \\
QRS (ms) & $108.9 \pm 21.6^{\mathrm{a}}$ & $102.1 \pm 14.5^{\mathrm{a}}$ & 0.0806 \\
QT (ms) & $464.6 \pm 39.4^{\mathrm{a}}$ & $385.2 \pm 49.6^{\mathrm{b}}$ & $<0.0001$ \\
QTc & $398.7 \pm 39.1^{\mathrm{a}}$ & $431.4 \pm 28.1^{\mathrm{b}}$ & 0.0039 \\
\hline
\end{tabular}

*Different lowercase letters in the same line denote significant differences between mean values according to paired $\mathrm{t}$-test $(\mathrm{P}<0.05)$. 
higher values than the present study, 530ms with a HR of 30 beats minute ${ }^{-1}, 470 \mathrm{~ms}$ with a HR of 70 beats minute $^{-1}$, and $180 \mathrm{~ms}$ with a 240 beats minute $^{-1}$. Despite significant reduction in the QT interval after the marcha gait, it was possible to observe a significant increase in QTc, indicating alterations in ventricular repolarization. This significant increase in QTc reported after physical activity was not observed by FAZIO et al. (2003), but was also described by PICCIONE et al. (2003) and BELLO et al. (2012). According to PICCIONE et al. (2003), such finding is due to an increase in autonomic tonus. Also, it can be said that animals from present study did not suffer cardiac fatigue because values recorded for QTc were lower than interval between $450 \mathrm{~ms}$ and $500 \mathrm{~ms}$, suggested by SEVESTRE (1982) as being indicative of mild myocardial fatigue.

DOJANA et al. (2008) and ALBERNAZ et al. (2011) observed that physical training led to an increased R-wave amplitude, justifying this fact as a result of increased ventricular depolarization possibly caused by hypertrophy or hyperplasia of the heart chamber (greater Purkinje fibers distribution). However, YONEZAWA et al. (2009) and BELLO et al. (2012) reported minimal effects on QRS complex after a physical exercise session, unlike findings observed here, where a significant increase in the R-wave amplitude after physical activity was observed.

During $\mathrm{T}$ wave polarity analysis before gait, it was possible to observe that $79.2 \%$ were positive monophasic, $8.3 \%$ were negative monophasic, and $12.5 \%$ biphasic. After physical activity, $\mathrm{T}$ wave showed positive single-phase polarity in $20.8 \%$, negative monophasic in $16.7 \%$ and biphasic in $62.5 \%$ of the animals studied. Preexercise findings were similar to those described by DOJANA et al. (2008), who reported a predominance of positive monophasic $\mathrm{T}$ waves in $65 \%$ of the equine athletes studied, but quite different from DINIZ et al. (2008), which reported biphasic T waves predominance $(61.7 \%)$.

Also according to DINIZ et al. (2008), $20 \%$ of $\mathrm{T}$ waves were negative and $18.3 \%$ presented positive. Changes in polarity of T-wave were described by PICCIONE et al. (2003), with physical stress as the primary cause. However, according to SEVESTRE (1982) and ALBERNAZ et al. (2011), T-wave characteristics showed to be a very variable parameter, in which alterations can persist even after exercise conclusion (MARR \& BOWEN, 2010).

\section{CONCLUSION}

It was concluded, based on results of the present study, that type of physical exercise imposed led to an increase in heart rate, with reduction in $\mathrm{P}$-wave duration as well as PR and QT intervals. Despite reduction in QT interval after exercise, there was an increase in QTc, indicating changes in ventricular repolarization without generating myocardial fatigue.

\section{BIOETHICS AND BIOSSECURITY COMMITTEE APPROVAL}

The present study was approved by the Ethics Committee, Bioethics and Animal Welfare (CEUA - UVV-ES) (177/2011).

\section{ACKNOWLEDGMENTS}

The Fundação de Amparo à Pesquisa e Inovação do Estado do Espírito Santo (FAPES), for the financial support (registration number 54668476/2011).

\section{REFERENCES}

ALBERNAZ, R.M. et al. Equine electrocardiographic responses to training based on speed-lactate curve performed on treadmill. Ciência Animal Brasileira, v.12, p.163-171, 2011. Available from: $<$ http://www. revistas.ufg.br/index.php/vet/article/view/8145>. Accessed: 20 Jan. 2015.

ALONSO, D.O. et al. Heart rate response and its variability during different phases of maximal graded exercise. Arquivo Brasileiro de Cardiologia, v.71, p.787-792, 1998. Available from: $<\mathrm{http} / / \mathrm{dx}$.doi. org/10.1590/S0066-782X1998001200008>. Accessed: 20 Jan. 2015.

BARBESGAARD, L. et al. Prevalence of exercise-associated arrhythmias in normal performing dressage horses. Equine Veterinary Journal, v.42, p.202-207, 2010. Available from: <http:// www.ncbi.nlm.nih.gov/pubmed/21059007>. Accessed: 20 Jan. 2015.

BELLO, C.A.O. et al. Electrocardiographic evaluation of horses after polo exercise. Pesquisa Veterinária Brasileira, v.32, p.4752, 2012. Available from: <http://dx.doi.org/10.1590/S0100736X2012001300010>. Accessed: 15 Apr. 2015.

BUHL, R. et al. Cardiac arrhthmias in clinically healthy showjumping horses. Equine Veterinary Journal, v.42, p.196-201, 2010. Available from: <http://onlinelibrary.wiley.com/doi/10.1111/ j.2042-3306.2010.00185.x/abstract>. Accessed: 15 Mar. 2015.

CAPELLETO, E.C. et al. Physiological answers in quarter horses after barrel racing. Revista Acadêmica de Ciência Agrária Ambiental, v.7, p.299-304, 2009. Available from: <http://www2. pucpr.br/reol/pb/index.php/academica?dd1=3463\&dd99=view \&d d98=pb $>$. Accessed: 15 Apr. 2015.

DINIZ, M.P. et al. Electrocardiographic study in horses of the Mangalarga Marchador breed. Arquivo Brasileiro de Medicina Veterinária e Zootecnia, v.60, p.536-542, 2008. Available from: $<$ http://www.scielo.br/ pdf/abmvz/v60n3/03.pdf >. Accessed: 15 Aug. 2014. 
DOJANA, N. et al. Electrocardiographic parameters of the sport horse. Zootehnie I Biotehnologii, v.41, p.397-401, 2008. Available from: <http://spasb.ro/index.php/spasb/article/ download/1221/1171>. Accessed: 15 Apr. 2010.

DUMONT, C.B.S. et al. Electrocardiographic parameters of Arabian horses submitted to prolonged exercise of endurance. Ciência Rural, v.40, n.9, p.1966-1973, 2010. Available from: <http://dx.doi. org/10.1590/S0103-84782010000900018>. Accessed: 15 Mar. 2015.

FALASCHINI, A.; TROMBETTA, M.F. Modifications induced by training and diet in some exercise-related blood parameters in young trotters. Journal of Equine Veterinary Science, v.1, p.601-604, 2001. Available from: <http://www.j-evs.com/article/ S0737-0806(01)80021-6/abstract $>$. Accessed: 15 Mar. 2010.

FAZIO, F. etal. Variations in some electrocardiographic parameters in the trotterduringracingandtraining. VeterinaryResearchCommunications, v. 27, p.229-232, 2003. Available from: <http://link.springer.com/ article/10.1023\%2FB\%3AVERC.0000014147.80127.03\#page-1>. Accessed: 15 Mar. 2015.

FERNANDES, W.R. et al. Electrocardiographic parameters in clinically healthy Thoroughbred horses. Arquivo Brasileiro de Medicina Veterinária e Zootecnia, v.56, p.143-149, 2004. Available from: <http://dx.doi.org/10.1590/S010209352004000200002>. Accessed: 15 Jul. 2011.

FERRAZ, G.C. et al. Hematological and cardiac alterations in Arabian horses submitted to incremental effort test in treadmill. Brazilian Journal of Veterinary Research and Animal Science, v.46, p.431-437, 2009. Available from: <http://dx.doi.org/10.1590/ S1413-95962009000600001>. Accessed: 15 Aug. 2014.

FOLADOR, J.C. et al. Serum concentration of sodium, potassium and calcium in Mangalarga Marchador horses after physical exercise. Archives of Veterinary Science, v.19, p.60-68, 2014. Available from: <http://ojs.c3sl.ufpr.br/ojs/index.php/veterinary/ article/viewFile/34143/22523>. Accessed: 15 Apr. 2015.

GAMA, J.N.A. et al. Serum aspartate aminotransferase and creatine kinase concentrations and plasma lactate in Mangalarga Marchador horses after physical exercise. Brazilian Journal of Veterinary Research and Animal Science, v.49, n.6, p.480-486, 2012. Available from: $<\mathrm{http}: / / \mathrm{dx}$.doi. org/10.11606/issn.1678-4456.v49i6p480-486>. Accessed: 15 Apr. 2013.

LISBOA, F.P. et al. Dados preliminares do padrão eletrocardiográfico de equinos da raça Crioula, PELOTAS, RS, 2009. In: CIC, 18.; ENPOS, 11., 2009, Pelotas, RS. Anais... Pelotas: Universidade Federal de Pelotas, 2009. Available from: $<$ http://www2.ufpel.edu. br/cic/2009/cd/pdf/CA/CA_02098.pdf >. Accessed: 15 Apr. 2010.

MARQUES, M.S. et al. Influência do exercício físico sobre os níveis de lactato plasmatico e cortisol sérico em cavalos de corrida. A Hora Veterinária, v.22, p.29-32, 2002.

MARR, C.M.; BOWEN, I.M. Cardiology of the horse Philadelphia: Saunders, 2010. 288p.

MARTIN, B.B. et al. Causes of poor performance of horses during training, racing, or showing: 348 cases (1992-1994). Journal of American Veterinary Medical Association, v.216, p.554-558, 2000.

MORRIS, E.H.; SEEHERMAN, H.J. Clinical evaluation of poor performance in the racehorse: the results of 275 evaluations. Equine
Veterinary Journal, v.23, p.169-174, 1991. Available from: $<$ http://onlinelibrary.wiley.com/doi/10.1111/j.2042-3306.1991. tb02749.x/pdf>. Accessed: 15 Mar. 2015.

MENDES, D.N. Semiologia do sistema circulatório de equinos e ruminantes. In: FEITOSA, F.L.F. Semiologia Veterinária: a arte do diagnóstico. São Paulo: Rocca, 2004. p.234-277.

PEDERSEN, P. et al. Normal electrocardiographic QT interval in race-fit Standardbred horses at rest and its rate dependence during exercise. Journal of Veterinary Cardiology, v.15, p.23-31, 2013. Available from: $<$ http://www.sciencedirect.com/science/article/pii/ S1760273413000027>. Accessed: 15 Mar. 2015.

PICCIONE, G. et al. Electrocardiographic changes induced by physical exercise in the jumper horse. Arquivo Brasileiro de Medicina Veterinária e Zootecnia, v.55, p.397-404, 2003. Available from: <http://dx.doi.org/10.1590/S010209352003000400003>. Accessed: 15 Aug. 2014.

REZENDE, A.S.C. Aditivos ou suplementos? Mangalarga Marchador. Revista Oficial da ABCCMM, v.18, p.44-48, 2006.

ROBINSON, E.N. Current therapy in equine medicine. 6.ed. Philadelphia: Saunders, 2008. 1066p.

RUMENIG, E. et al. Kinetics and heart rate variability during aerobic exercise: influence of the intensity and the period of analyze. Revista Brasileira de Educação Física, v.21, p.205218, 2007. Available from: <http://bases.bireme.br/cgi-bin/ wxislind.exe/iah/online/?IsisScript $=\mathrm{iah} / \mathrm{iah}$.xis $\&$ src $=$ google $\&$ bas $\mathrm{e}=$ LILACS\&lang $=\mathrm{p} \&$ nextAction $=\operatorname{lnk} \& \operatorname{exprSearch}=514189 \&$ ind exSearch=ID $>$. Accessed: 15 Aug. 2014.

SCHEFFER, C.J.W.; VAN OLDRUITENBORGHOOSTERBAAN, M.M.S. Computerized ECG recording in horses during a standardized exercise test. Veterinary Quaterly, v.18, p.2-7, 1996. Available from: $<\mathrm{http}: / / \mathrm{www} \cdot \operatorname{tandfonline.com/doi/pdf}$ /10.1080/01652176.1996.9694601>. Accessed: 15 Mar. 2015

SEVESTRE, J. A eletrocardiografia no cavalo. A Hora Veterinária, v.2, p.28-36, 1982.

TRACHSEL, D.S. et al. Observer agreement for detection of cardiac arrhythmias on telemetric ECG recordings obtained at rest, during and after exercise in 10 Warmblood horses. Equine Veterinary Journal, v.42, p. 208-215, 2010. Available from: <http://www.ncbi. nlm.nih.gov/pubmed/21059008>. Accessed: 15 Mar. 2015.

VINCENZI, R.C. et al. Parâmetros eletrocardiográficos de equinos clinicamente normais da raça Mangalarga. Parte I: frequência e ritmo cardíaco. Revista Brasileira de Medicina Veterinária, v.22, p.71-73, 2000.

YONEZAWA, L.A. et al. Electrocardiographic exam in Arabian horses submitted to exercise on high-speed treadmill and vitamin E supplementation. Archives of Veterinary Science, v.14, p.134-142, 2009. Available from: <http://dx.doi.org/10.5380/avs. v14i3.15839>. Accessed: 15 Mar. 2015.

YOUNG, L.E. Recent advances in diagnosing cardiac abnormalities with an ECG during exercise. A Review, Orlando, FL, 2007. In: Annual Convention of American Association of Equine Practitioners, 53., 2007, Orlando, Florida. Proceedings... Florida: AAEP, 2007. p.99-103. 